\title{
PENERAPAN MODEL DISCOVERY LEARNING UNTUK MENINGKATKAN HASIL BELAJAR PADA MATERI POKOK EROSI DAN TANAH DI KELAS $X$ SMA NEGERI 1 WABULA
}

\author{
Oktafianti $^{1}$, La Ode Amaluddin ${ }^{2}$ \\ ${ }^{1}$ Alumni Jurusan Pendidikan Geografi UHO \\ ${ }^{2}$ Dosen Jurusan Pendidikan Geografi UHO \\ email :Oktafianti022@gmail.com
}

\begin{abstract}
Abstrak: Tujuan dalam penelitian ini adalah: 1) Untuk mengetahui aktivitas belajar siswa kelas X SMA Negeri 1 Wabula dengan menerapkan model discovery learning pada materi pokok erosi dan kerusakan tanah. 2). Untuk mengetahui aktifitas mengajar guru pada siswa kelas XSMA Negeri 1Wabula dengan menerapkan model discovery learning pada materi pokok erosi dan kerusakan tanah. 3). Untuk mengetahui peningkatkan hasil belajar siswa melalui penerapan model discovery learning di kelas X SMA Negeri 1 Wabula pada materi pokok erosi dan kerusakan tanah.Penelitian ini dilaksanakan pada semester genap tahun pelajaran 2017/2018 mulai tanggal 17 maret 2017- 22 april 2017 di kelas X SMA Negeri 1 Wabula.Jenis penelitian ini adalah Penelitian Tindakan Kelas (PTK) yang telah dilaksanakan dengan dua siklus.Subjek penelitian ini adalah siswa kelas X SMA Negeri 1 Wabula semester genap tahun pelajaran 2017/2018 yang berjumlah 16.Data dalam penelitian ini adalah data kualitatif dan data kuantitatif yang diperoleh dari lembar observasi dan tes hasil belajar. Dari hasil analisis data diperoleh kesimpulan bahwa: 1).Dengan skor rata-rata aktivitas siswa pada siklus I adalah 2,7, meningkat pada siklus II menjadi 3,4. 2). Dengan skor rata-rata pada siklus I aktivitas guru adalah 2,6 meningkat pada siklus II menjadi 3,4. 3). Hasil belajar siswa meningkat setelah menerapkan model discovery learning pada materi pokok erosi dan kerusakan tanah. Dimana pada siklus I yaitu diperoleh nilai terendah 20, nilai tertinggi 90Pada siklus II diperoleh nilai terendah 60, nilai tertinggi 95
\end{abstract}

Kata Kunci: Model Pembelajaran, Proses, dan Hasil Belajar. 
Jurnal Penelitian Pendidikan Geografi Volume 4 Nomor 1 Januari 2019

\title{
APPLICATION OF DISCOVERY LEARNING MODEL TO IMPROVE LEARNING OUTCOMES IN EROSION AND SOIL SUBSTANCES IN CLASS X STATE 1 STATE HIGH SCHOOL
}

\author{
Oktafianti $^{1}$, La Ode Amaluddin ${ }^{2}$ \\ ${ }^{1}$ Alumnus of Department of Geography Education UHO \\ ${ }^{2}$ Lecturer of Department of Geography Education UHO \\ email: Oktafianti022@gmail.com
}

\begin{abstract}
The objectives of this study are as follows: 1) To identify the learning activities of SMA Negeri 1 Wabula class $X$ students by applying discovery learning models to the issue of erosion and damage to children. ground. 2) Know the teaching activities of the teachers of the SMA 1 Wabula class $\mathrm{X}$ by applying discovery learning models to the issue of erosion and ground damage. 3) Discover the improvement of student learning outcomes through the application of discovery learning models in SMA 1 Wabula class X in the field of erosion and ground damage. This research was conducted during the peer semester of the 2017/2018 school year, from March 17, 2017 to April 22, 2017, in class X SMA 1 Wabula. This type of research is the Classroom Action Research (CAR) which was carried out in two cycles. The subjects of this study were the grade 10 students of SMA Negeri 1 Wabula same school year 2017/2018, being 16 years old. The data in this study were qualitative data and quantitative data obtained from observation cards and tests of learning outcomes. The results of the data analysis suggest that: 1). The average student activity score in Cycle I was 2.7, and in Cycle II it was 3.4. 2) With the average score in the first cycle, the teacher's activity was increased from 2.6 in the second cycle to 3.4. 3) Student learning outcomes increase following the application of the learning by discovery model of erosion and ground damage. When, in the first cycle, the lowest value of 20 is obtained, the highest value of 90 in the second cycle gets the lowest value of 60 , the highest value of 95
\end{abstract}

Keywords: learning model, process and learning outcomes.

\section{PENDAHULUAN}

Indonesia merupakan negara kepulauan yang memiliki potensi cukup besar, kaya dengan keaneka ragaman yang begitu menjanjikan. Namun melihat dari latar belakang pendidikan indonesia merupakan negara yang masih cukup tertinggal di bidang ilmu pengetahuan. Pendidikan merupakan suatu cara pembentukan kemampuan manusia untuk menggunakan akal fikiran/rasional mereka sebagai jawaban dalam menghadapi berbagai masalah yang timbul dimasa yang akan datang.

\begin{abstract}
Pendidikan juga merupakan usaha sadar yang sengaja dirancang untuk mencapai tujuan yang telah ditetapkan. Salah satu tujuan pendidikan yaitu untuk meningkatkan kualitas sumber daya manusia. Melalui pendidikan yang baik, kita akan mudah mengikuti perkembangan zaman dimasa yang akan datang, khususnya perkembangan dalam bidang Ilmu Pengetahuan dan Teknologi (IPTEK).
\end{abstract}

Berhasilnya suatu tujuan pendidikan tergantung pada bagaimana proses belajar mengajar yang di alami oleh siswa. Seorang guru di tuntut untuk teliti dalam memilih dan menerapkan metode mengajar yang 
sesuai dengan tujuan yang ingin di capai. Menciptakan kegiatan belajar mengajar yang mampu menciptakan hasil belajar yang efektif merupakan tugas dan kewajiban guru. Menurut Slameto (2003). Namun perlu diketahui beberapa penerapan pengajaran yang masih kurang efisien telah menjadi pokok masalah pada siswa Kelas X di SMA Negeri 1 Kecamatan Wabula Kabupaten Buton. Yang mana pelajar masih kurang mendapatkan penyampaian yang dapat membuka pola fikir sebagai mana mestinya.

Hal ini menunjukan bahwa pembelajaran geografi belum efisien dengan metode pembelajaran yang telah di perlakukan pada siswa SMA Negeri 1 Wabula, di mana proses belajar mengajar di monopoli oleh guru dengan penerapan model materi yang bersifat konvensional seperti metode ceramah dan diskusi sehingga siswa tidak banyak terlibat aktif dalam pembelajaran. Selain itu, materi yang dijelaskan juga jauh dari kehidupan nyata siswa sehingga materi susah diserap dan dipahami siswa.

Hal ini seharusnya mendapat perhatian lebih dari semua pihak (stakeholder) khususnya guru pengampuh mata pelajaran tersebut untuk mencari solusi atau alternatif dalam rangka perbaikan proses pembelajaran di dalam kelas. Salah satu solusi atau alternatif yang bisa diterapkan guru di kelas adalah dengan menggunakan model Discovery learning dalam proses pembelajaran. Dengan model Discovery learning, siswa lebih aktif dan mudah memahami materi. Dalam penerapan model discovery learning di kelas, guru lebih banyak berurusan dengan strategi daripada member informasi. Belajar akan lebih bermakna jika anak mengalami apa yang dipelajarinya,bukan mengetahuinya. Pembelajaran yang berorientasi pada penguasaan materi terbukti berhasil dalam kompetisi mengingat jangka pendek tetapi gagal dalam membekali anak memecahkan persoalan dalam kehidupan jangka panjang (Aqib, 2015: 1).

Model Discovery Learning adalah teori belajar yang didefinisikan sebagai proses pembelajaran yang terjadi bila pelajar tidak disajikan dengan pelajaran dalam bentuk finalnya, tetapi diharapkan mengorganisasi sendiri dimana murid mengorganisasi bahan yang dipelajari dengan suatu bentuk akhir (Dalyono, 1996:41).

Metode Discovery Learning adalah memahami konsep, arti, dan hubungan, melalui proses intuitif untuk akhirnya sampai kepada suatu kesimpulan (Budiningsih, 2005:43). Discovery terjadi bila individu terlibat, terutama dalam penggunaan proses mentalnya untuk menemukan beberapa konsep dan prinsip. Discovery dilakukan melalui observasi, klasifikasi, pengukuran, prediksi, penentuan dan inferi.

Dalam kelas yang di terapkan dengan model discovery tugas guru ialah membantu siswa dalam mencapai tujuannya. Guru lebih banyak berurusan dengan strategi daripada memberi informasi berupa masalah yang di rekayasa oleh guru berupa materi atau bahan pelajaran yang akan disampaikan dalam bentuk final akan tetapi siswa sebagai peserta didik didorong untuk mengidentifikasi apa yang ingin diketahui dilanjutkan dengan mencari informasi sendiri kemudian mengorgansasi atau membentuk (konstruktif) apa yang mereka ketahui dan mereka pahami dalam suatu bentuk akhir.

Berdasarkan uraian di atas, maka dengan menggunakan model Discovery Learning diharapkan dapat meningkatkan hasil belajar Geografi siswa kelas X SMA Negeri 1 Wabula. Oleh karena itu, peneliti 
tertarik untuk melakukan penelitian dengan judul "Penerapan Model Discovery Learning untuk Meningkatkan Hasil Belajar pada Materi Pokok Erosi dan Kerusakan Tanah di Kelas X SMA Negeri 1 Wabula.

\section{Jenis Penelitian}

Sesuai dengan masalah yang diteliti maka jenis penelitian ini, penelitian tindakan kelas (PTK) yaitu suatu penelitian yang dilakukan dengan model discovery learning yang bertujuan untuk mengatasi masalah pola fikir siswa/i pada materi pokok erosi dan kerusakan tanah di kelas $\mathrm{X}$ SMA Negeri 1 Wabula dalam mata pelajaran geografi.

\section{Subyek Dan Informasi Penelitian}

Subyek penelitian adalah siswa kelas $\mathrm{X}$ SMA Negeri 1 Wabula yang terdaftar pada semester genap tahun pelajaran 2016/2017 yang berjumlah 16 orang siswa,terdiri dari 14 orang siswa laki-laki dan 2 orang siswa perempuan. Kelas ini dipilih sebagai subyek penelitian karena berdasarkan data hasil belajar siswa di kelas $\mathrm{X}$ masih tergolong rendah.

\section{Desain dan Prosedur Penelitian}

Desain model Penelitian Tindakan Kelas (PTK) ini terdiri atas 4 (empat) tahap, yakni: perencanaan, pelaksanaan tindakan, pengamatan/evaluasi dan Refleksi. Secara rinci penelitian tindakan kelas ini dapat dijabarkan seperti pada gambar:

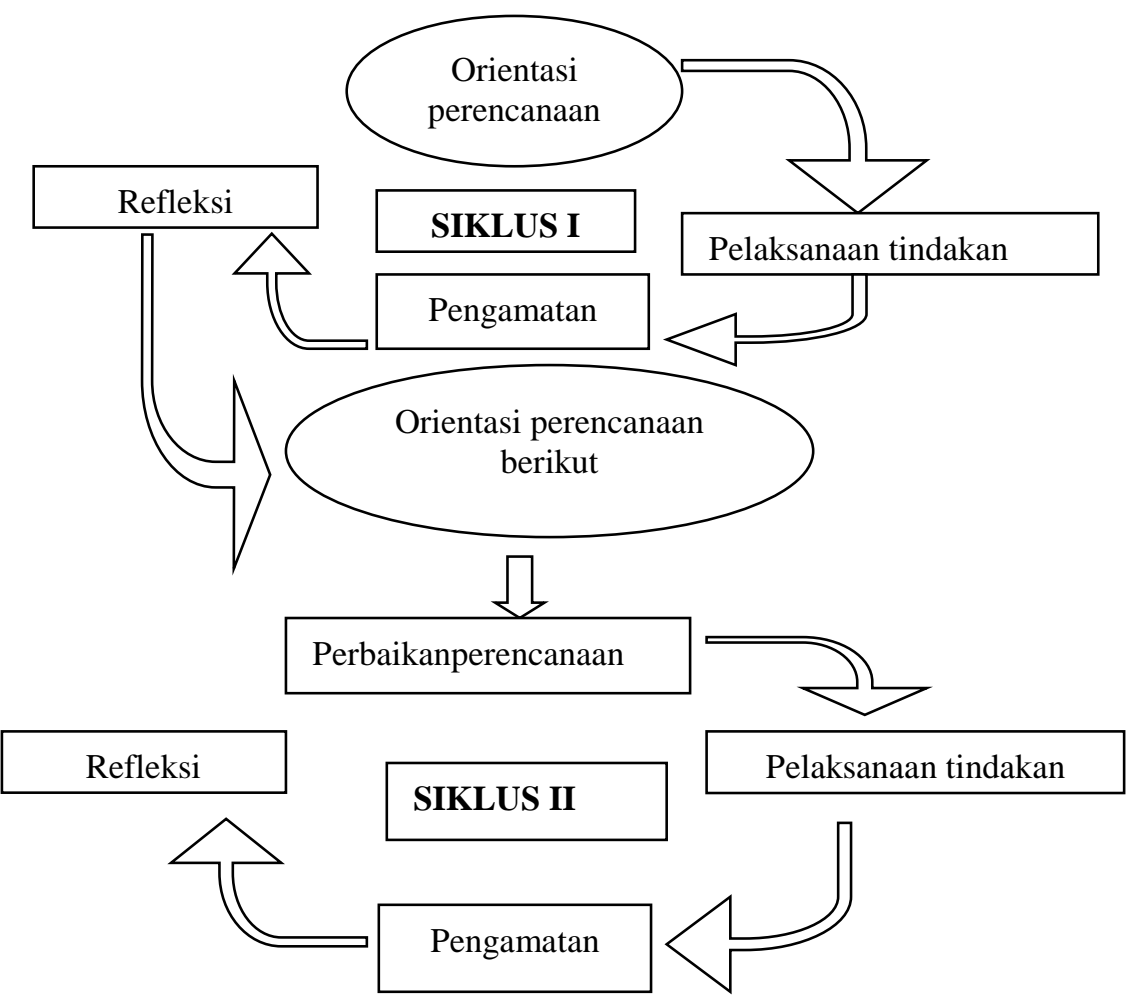

Oktafianti, La Ode Amaluddin 
Gambar 2.1 Desain penelitian tindakan kelas(Iskandar, 2012:67)

\section{Data dan Teknik Pengumpulan Data}

Sumber data penelitian adalah guru dan siswa yang meliputi: a) hasil observasi aktivitas belajar siswa; b) hasil observasi aktivitas mengajar guru; dan c) hasil belajar siswa.

Jenis data yang diperoleh adalah data kuantitatif dan data kualitatif. Data kuantitatif diperoleh dari tes hasil belajar sedangkan data kualitatif diperoleh dari lembar observasi.

Teknik pengumpulan data dalam penelitian ini adalah sebagai berikut:

- Data mengenai aktivitas siswa diambil dengan menggunakan lembar observasi dengan cara memberikan skor pada aspek aktivitas yang dilakukan untuk siswa sesuai dengan kriteria yang telah ditentukan.

- Data mengenai hasil belajar Geografi diambil dengan menggunakan tes hasil belajar (tes siklus) dengan bentuk tes berupa tes essay yang mencakup semua indikator pembelajaran pada siklus I serta siklus II.

Data dalam penelitian ini dianalisis dengan menggunakan analisis deskriptif kualitatif dan kuantitatif. Analisis deskriptif kualitatif digunakan untuk memberikan penjelasan mengenai aktivitas siswa serta kemampuan guru selama proses pembelajaran berlangsung, sedangkan analisis deskriptif kuantitatif digunakan untuk menyajikan persentase aktivitas guru dalam mengelola pembelajaran, persentase aktivitas siswa dan presentase ketuntasan hasil belajar siswa. Langkah-langkah analisis data sebagai berikut:
Dalam menentukan nilai hasil belajar siswa, rentang nilai yang digunakan untuk tes uraian dalam penelitian ini adalah 0 sampai 100 dengan rumus:

$X_{i}=\frac{S p i}{S m} \times 100$ (Usman dan Setiawati, 2001).

Menghitung Standar Deviasi (SD) dengan menggunakan rumusSD (Sudjana, 2002: 93).

$$
=\sqrt{\frac{\sum_{i=1}^{n}(\mathrm{Xi}-\bar{X})^{2}}{n-1}}
$$

Menghitung nilai rata-rata hasil belajar siswa, dengan rumus:(Sudjana, 2002: 67).

$$
\bar{X}=\frac{\sum_{i=1}^{n} X_{i}}{n}
$$

Menentukan tingkat pencapaian ketuntasan belajar

Presentase jumlah siswa yang hasil belajarnya sudah tuntas, dengan menggunakan rumus:

$\%$ Tuntas $=\frac{\sum T B}{N} X 100 \%($ Sudjana, 2002 :67)

Mengklasifikasikan rata-rata aktivitas siswa dalam kategori sebagai berikut :

$1=$ Kurang baik

$2=$ Cukup baik

$3=$ Baik

$4=$ Sangat baik

\section{Indikator Keberhasilan}

Pelaksanaan tindakan kelas ini dipandang berhasil apabila sudah memenuhi indikator keberhasilan tindakan sebagai berikut: 
1. Secara proses, jika skor rata-rata aktivitas siswa minimal 3,0.

2. Secara individu, jika hasil belajar Geografi siswa yang menjadi subjek penelitian ini telah mencapai Kriteria Ketuntasan Minimal (KKM) 70 dari nilai ideal 100.

3. Secara klasikal, jika $75 \%$ dari jumlah siswa yang menjadi subjek penelitian mendapat nilai serendah-rendahnya 70 berdasarkan Kriteria Ketuntasan Minimal (KKM).

\section{HASIL PENELITIAN}

\section{Data Aktivitas Belajar Siswa}

Data mengenai aktivitas siswa kelas $\mathrm{X}$ SMA Negeri 1 Wabula selama pelaksanaan pembelajaran dengan menerapkan model discovery learning pada materi pokok erosi dan kerusakan tanah yang diperoleh dengan menggunakan lembar observasi aktivitas siswa dengan cara memberikan skor keterlaksanaan pada setiap aspek aktivitas dapat dilihat pada tabel 4.1 berikut :

Tabel 3.1 Skor Rata-rata Aktivitas Siswa pada Setiap Siklus I.

\begin{tabular}{clccc}
\hline \multirow{2}{*}{ No } & \multicolumn{1}{c}{ Aktivitas Siswa yang dinilai } & \multicolumn{2}{c}{ Siklus I } & \multirow{2}{*}{$\begin{array}{c}\text { Rata - } \\
\text { rata }\end{array}$} \\
\cline { 3 - 4 } & & $\begin{array}{c}\text { Pert } \\
\text { I }\end{array}$ & $\begin{array}{c}\text { Pert } \\
\text { II }\end{array}$ & \\
\hline 1 & $\begin{array}{l}\text { Mendengarkan dan memperhatikan guru dalam } \\
\text { menyampaikan tujua pembelajaran }\end{array}$ & 2.5 & 3.0 & 2.8 \\
\hline 2 & $\begin{array}{l}\text { Siswa mendengarkan /memperhatikan penjelasan guru } \\
\text { mengenai materi pembelajaran }\end{array}$ & 2.8 & 3.0 & 2.9 \\
\hline 3 & $\begin{array}{l}\text { Menjawab pertanyaan yang di berikan oleh guru } \\
\text { dengan benar }\end{array}$ & 1.8 & 2.3 & 2.1 \\
\hline 4 & $\begin{array}{l}\text { Mencari kelompok masing -asing yang telah di bagi } \\
\text { oleh guru }\end{array}$ & 2.3 & 2.5 & 2.4 \\
\hline 5 & $\begin{array}{l}\text { Siswa berdiskusi dengan kelompok yang telah di } \\
\text { tentukan oleh guru }\end{array}$ & 2.5 & 2.5 & 2.5 \\
\hline 6 & $\begin{array}{l}\text { Bekerjasama dalam menyelesaikan masalah yang ada } \\
\text { pada LKS dan mampu mengumpulkan data pada topik } \\
\text { masalah yang telah di tentukan. }\end{array}$ & 2.5 & 2.5 & 2.5 \\
\hline 7 & $\begin{array}{l}\text { Bekerja sama dalam mengolah data dan menyiapkan } \\
\text { laporan hasil diskusi kelompok }\end{array}$ & 3.0 & 3.0 & 3.0 \\
\hline 8 & $\begin{array}{l}\text { Masing masing kelompok mempersentasikan hasil } \\
\text { diskusi di depan kelas }\end{array}$ & 2.8 & 3.0 & 2.9 \\
\hline 9 & Menyimak dan menanggapi hasil diskusi kelompok lain & 2.8 & 2.8 & 2.8 \\
\hline 10 & $\begin{array}{l}\text { Menyimak penguatan dan koreksi dari guru tentang } \\
\text { diskusi kelompok }\end{array}$ & 2.8 & 3.0 & 2.9 \\
\hline Rata rata aktivitas siswa untuk semua aspek & $\mathbf{2 . 6}$ & $\mathbf{2 . 8}$ & $\mathbf{2 . 7}$ \\
\hline Kategori & & \multicolumn{2}{c}{ Cukup } \\
\hline
\end{tabular}

Untuk mendapatkan gambaran rata-rata aktivitas siswa selama pembelajaran pada siklus I pertemuan I dan II dapat di lihat pada grafik 3.1 berikut : 
rata-rata aktivitas belajar siswa siklus 1

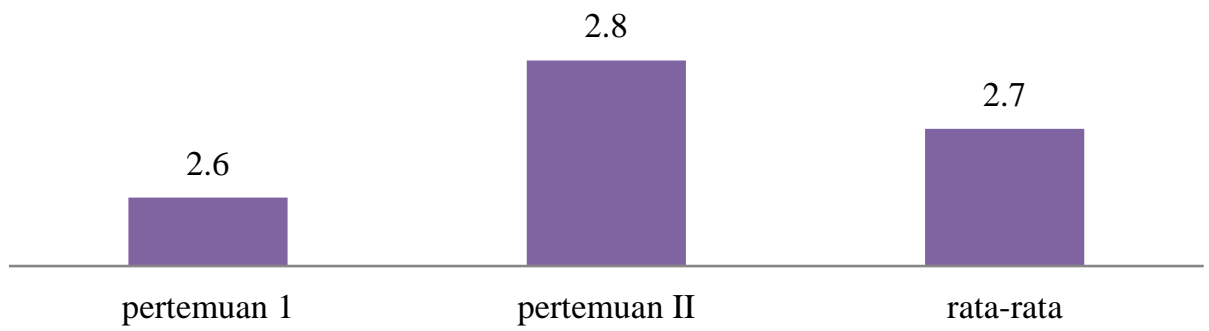

Grafik 3.1 rata rata aktivitas siswa siklus I data di buat (januari 2018)

\section{DataAktivitas Mengajar Guru Siklus I}

\begin{abstract}
Gambaran aktivitas guru dalam mengelola pembelajaran dengan menggunakan model discovey learning pada materi pokok erosi dan kerusakan tanah yang diperoleh dengan menggunakan lembar observasi aktivitas guru pada siklus I dapat dilihat pada tabel 3.2 berikut:

Berdasarkan tabel 3.2 menunjukkan bahwa, aktivitas guru masih belum memenuhi kriteria ketuntasan minimal yaitu 3,0 karena rata-rata aktivitas guru secara keseluruhan masih mencapai 2,6 yang berkategorikan cukup yaitu.
\end{abstract}

- Guru melakukan apresiasi tentang materi yang akan di pelajari, dengan skor 2,5

- Guru menyampaikan indikator dan tujuan pembelajaran, dengan skor 2,5

- Guru memberi motivasi kepada siswa, dengan skor 2
- Guru membagi siswa yang terdiri dari 4 kelompok siswa yang heterogen, dengan skor 2,5

- Guru memberikan gambaran suatu masalah kepada siswa dan mengorganisasikan siswa untuk belajar dan berdiskusi untuk memecahkan masalahyang terdapat pada LKS, dengan skor 2,5

- Mengarahkan kepada tiap-tiap individu dalam kelompok untuk melakukan identifikasi masalah dan mengumpulkan data, dengan skor 2,5

- Guru memberikan kesimpulan secara singkat tentang materi yang telah di presentasikan perwakilan siswa, dengan skor 2

- Guru mengevaluasi dan merefleksi secara singkat sajian materi yang disajikan oleh perwakilan siswa, dengan skor 2,5

- Memberi tugas kepada siswa terkait materi yang sudah di pelajari, dengan skor 2 
Tabel 3.2 skor rata-rata aktifitas mengajar guru

\begin{tabular}{|c|c|c|c|c|}
\hline \multirow{2}{*}{ No } & \multirow{2}{*}{ Aspek yang di nilai } & \multicolumn{3}{|c|}{ Skor/ siklus I } \\
\hline & & Per I & $\begin{array}{c}\text { Per } \\
\text { II }\end{array}$ & $\begin{array}{r}\text { Rata- } \\
\text { rata }\end{array}$ \\
\hline \multirow{5}{*}{$\mathrm{I}$} & A. Kegiatan Awal & & & \\
\hline & $\begin{array}{l}\text { 1. Membuka pelajaran dan memeriksa kesiapan } \\
\text { siswa. }\end{array}$ & 3 & 3 & 3 \\
\hline & $\begin{array}{l}\text { 2. Guru menyampaikan indikator dan tujuan } \\
\text { pembelajaran }\end{array}$ & 2 & 3 & 2.5 \\
\hline & $\begin{array}{l}\text { 3. Guru memberiakan stimulasi kepada siswa } \\
\text { terkait pembelajaran }\end{array}$ & 2 & 3 & 2.5 \\
\hline & 4. Guru memberikan motivasi kepada siswa & 2 & 2 & 2 \\
\hline \multirow{6}{*}{ II } & $\begin{array}{l}\text { B. Kegiatan Inti } \\
\text { 5. Guru membagi siswa yang terdiri } 4 \\
\text { kelompok siswa yang heterogen }\end{array}$ & 2 & 3 & 2.5 \\
\hline & $\begin{array}{l}\text { 6. Guru memberikan lembar kerja siswa (LKS) } \\
\text { kepada masing-masing kelompok dan } \\
\text { menentukan topik-topik yang harus di } \\
\text { pelajari serta memberi rangsangan pada } \\
\text { sebuah topik permasalahan dalam (LKS) } \\
\text { yang dibagikan }\end{array}$ & 3 & 3 & 3 \\
\hline & $\begin{array}{l}\text { 7. Guru memberikan gambaran suatu masalah } \\
\text { kepada siswa dan mengorganisasikan siswa } \\
\text { untuk belajar dan berdiskusi untuk } \\
\text { memecahkan masalah yang terdapat pada } \\
\text { LKS }\end{array}$ & 2 & 3 & 2.5 \\
\hline & $\begin{array}{l}\text { 8. Mengarahkan kepada tiap-tiap individu } \\
\text { dalam kelompok untuk melakukan } \\
\text { identifikasi masalah dan mengumpulkan } \\
\text { data. }\end{array}$ & 2 & 3 & 2.5 \\
\hline & $\begin{array}{l}\text { 9. Guru Meminta tiap-tiap perwakilan } \\
\text { kelompok untuk mempresentasikan hasil } \\
\text { pengolahan data yang telah didiskusikan di } \\
\text { depan kelas }\end{array}$ & 3 & 3 & 3 \\
\hline & $\begin{array}{l}\text { 10. Guru membimbing jalannya diskusi dan } \\
\text { tanya jawab dengan siswa }\end{array}$ & 3 & 3 & 3 \\
\hline \multirow[t]{2}{*}{ III } & $\begin{array}{l}\text { C. Kegiatan Akhir } \\
\text { 11. Guru memberikan kesimpulan secara singkat } \\
\text { tentang materi yang telah dipresentasikan } \\
\text { perwakilan siswa }\end{array}$ & 2 & 2 & 2 \\
\hline & $\begin{array}{l}\text { 12. Guru mengevaluasi dan merefleksi secara } \\
\text { singkat sajian materi yang disajikan oleh }\end{array}$ & 2 & 3 & 2.5 \\
\hline
\end{tabular}


perwakilan siswa

13. Memberi tugas kepada siswa terkait materi yang sudah di pelajari.

14. Menutup proses kegiatan pembelajaran

Rata-rata aktivitas guru

Kategori

\begin{tabular}{ccc}
1 & 3 & 2 \\
3 & 3 & 3 \\
\hline $\mathbf{2 . 4}$ & $\mathbf{2 . 9}$ & $\mathbf{2 . 6}$ \\
\hline & & Cukup
\end{tabular}

Untuk lebih jelasnya skor rata- rata aktivitas guru setiap pertemuan pada siklus I dapat di lihat pada gambar 3.2 berikut:

rata-rata aktivitas mengajar guru siklus I

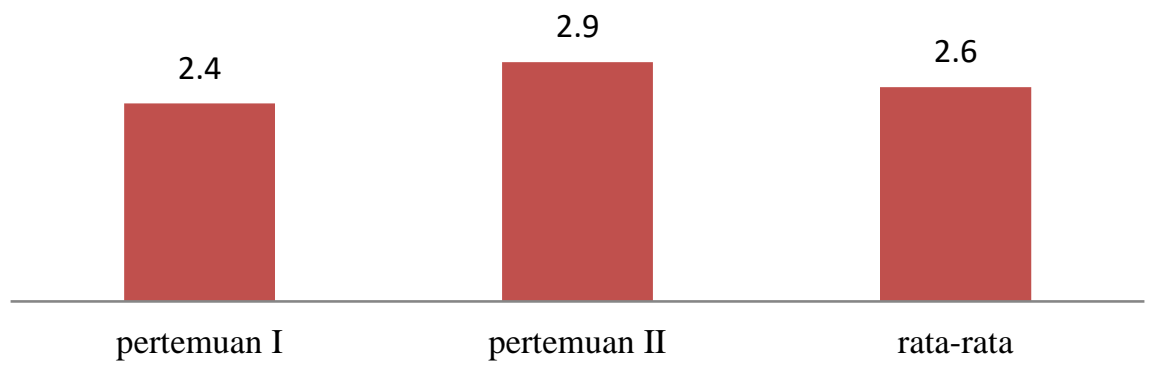

Grafik 3.2 skor rata tara aktivitas guru pada siklus I data di buat (januari 2018)

\section{Data Hasil Belajar Siswa Siklus I}

Data hasil belajar siswa kelas X IIS pada materi pokok erosi dan kerusakan tanah diperoleh dengan menggunakan lembar tes hasil belajar berupa soal essay yang diberikan pada akhir siklus I. Berdasarkan hasil analisis deskriptif terhadap hasil belajar pada setiap siklus tersebut, diperoleh data seperti tertera pada tabel 3.3 berikut:
Tabel 3.3 menunjukkan bahwa ketuntasan belajar siswa pada siklus I yang memperoleh skor antara 0-69 berjumlah 5 orang dengan presentase $40 \%$, sedangkan siswa yang telah memperoleh skor antara 70-100 berjumlah 11 orang dengan presentase ketuntasan mencapai $60 \%$ namun belum mencapai indikator ketuntasan keberhasilan dimana $75 \%$ siswa mencapai ketuntasan hasil belajar.

Berdasarkan hasil analisis data, hasil belajar siswa pada siklus I diperoleh hasil sebagaimana disajikan pada tabel 3.3

\begin{tabular}{cccc}
\hline Skor & $\begin{array}{c}\text { Jumlah } \\
\text { siswa }\end{array}$ & Presentase & Ketuntasan Belajar \\
\hline $0-69$ & 5 orang & $40 \%$ & Tidak Tuntas \\
\hline $70-100$ & 11 orang & $60 \%$ & Sudah Tuntas \\
\hline Jumlah & 16 orang & $\mathbf{1 0 0 \%}$ & \\
\hline
\end{tabular}




\begin{tabular}{ll}
\hline Keterangan : & \\
\hline Tuntas: 11 orang & \\
\hline Tidak tuntas & $: 5$ orang \\
\hline Nilai rata-rata & $: 6,1$ \\
\hline Nilai maksimum & $: 90$ \\
\hline Nilai minimum & $: 20$ \\
\hline Presentase ketuntasan & $: 60 \%$ \\
\hline
\end{tabular}

\section{Refleksi Tindakan Siklus I}

\section{$\checkmark$ Aktivitas belajar siswa}

Dari data aktivitas belajar siswa, terdapat kegiatan yang berkategori baik yaitu aktivitas siswa nomor 7 dengan skor 3,0. Dan aktivitas yang berkategori cukup akan di perbaiaki pada siklus II.

\section{$\checkmark \quad$ Aktivitas mengajar guru}

Selain aktivitas siswa, peneliti dan observer juga melakukan analisis dan refleksi kelemahan-kelemahan pelaksanaan model discovery learning.

\section{$\checkmark \quad$ Hasil belajar siswa}

Pada siklus I terdapat 5 orang siswa belum mencapai KKM dan 11 orang siswa yang sudah mencapai KKM, ketidak tercapainnya KKM di sebabkan oleh beberapa faktor yaitu:
Dari hasil ketuntasan belajar dinyatakan bahwa presentase hasil belajar siswa belum memenuhi kriteria ketuntasan belajar secara klasikal yang ditetapkan yaitu $60 \%$ dari $75 \%$, di mana terdapat 4 orang siswa yang belum mencapai nilai KKM dari 16 orang siswa sehingga dilanjutkan pada siklus II agar terjadi peningkatan prestasi belajar siswa dengan mengoptimalkan langkahlangkah model discovery learning.

\section{Data aktifitas siswa siklus II}

Data mengenai aktivitas siswa kelas $\mathrm{X}$ SMA Negeri 1 Wabula selama pelaksanaan pembelajaran dengan menerapkan model discovery learning pada materi pokok erosi dan kerusakan tanah yang diperoleh dengan menggunakan lembar observasi aktivitas siswa pada setiap pertemuan dengan cara memberikan skor keterlaksanaan pada setiap aspek aktivitas dapat dilihat pada tabel 3.4 berikut:

Tabel 3.4 Rata-rata Aktivitas Siswa Pada Siklus II

\begin{tabular}{clccc}
\hline No & \multicolumn{1}{c}{ Aktivitas Siswa yang dinilai } & \multicolumn{2}{c}{ Siklus II } & \multirow{2}{*}{$\begin{array}{c}\text { Rata - } \\
\text { rata }\end{array}$} \\
\cline { 3 - 4 } & $\begin{array}{c}\text { Pert } \\
\text { I }\end{array}$ & $\begin{array}{c}\text { Pert } \\
\text { II }\end{array}$ & \\
\hline & $\begin{array}{l}\text { Mendengarkan dan memperhatikan guru dalam } \\
\text { menyampaikan tujua pembelajaran }\end{array}$ & 3.0 & 4.0 & 3.5 \\
\hline 2 & $\begin{array}{l}\text { Siswa mendengarkan /memperhatikan penjelasan } \\
\text { guru mengenai materi pembelajaran }\end{array}$ & 3.0 & 4.0 & 3.5 \\
\hline 3 & $\begin{array}{l}\text { Menjawab pertanyaan yang di berikan oleh guru } \\
\text { dengan benar }\end{array}$ & 3.0 & 3.5 & 3.3 \\
\hline 4 & Mencari kelompok masing -asing yang telah di & 3.0 & 3.5 & 3.3 \\
\hline
\end{tabular}




\begin{tabular}{clccc}
\hline & bagi oleh guru & & \\
\hline 5 & $\begin{array}{l}\text { Siswa berdiskusi dengan kelompok yang telah di } \\
\text { tentukan oleh guru }\end{array}$ & 2.8 & 3.5 & 3.2 \\
\hline 6 & $\begin{array}{l}\text { Bekerjasama dalam menyelesaikan masalah yang } \\
\text { ada pada LKS dan mampu mengumpulkan data } \\
\text { pada topik masalah yang telah di tentukan. }\end{array}$ & 3.0 & 3.5 & 3.3 \\
\hline 7 & $\begin{array}{l}\text { Bekerja sama dalam mengolah data dan } \\
\text { menyiapkan laporan hasil diskusi kelompok }\end{array}$ & 3.0 & 4.0 & 3.5 \\
\hline 8 & $\begin{array}{l}\text { Masing masing kelompok mempersentasikan hasil } \\
\text { diskusi di depan kelas }\end{array}$ & 3.3 & 3.8 & 3.6 \\
\hline 9 & $\begin{array}{l}\text { Menyimak dan menanggapi hasil diskusi } \\
\text { kelompok lain }\end{array}$ & 3.0 & 3.5 & 3.3 \\
\hline 10 & $\begin{array}{l}\text { Menyimak penguatan dan koreksi dari guru } \\
\text { tentang diskusi kelompok }\end{array}$ & 3.5 & 4.0 & 3.9 \\
\hline Rata rata aktivitas kelompok untuk semua aspek & $\mathbf{3 . 1}$ & $\mathbf{3 . 7}$ & $\mathbf{3 . 4}$ \\
\hline Kategori & & & Baik \\
\hline
\end{tabular}

Untuk mendapatkan gambaran rata-rata aktivitas siswa selama pembelajaran pada siklus II pertemuan I dan II dapat di lihat pada grafik 3.4 berikut :

rata-rata aktivitas siswa siklus II

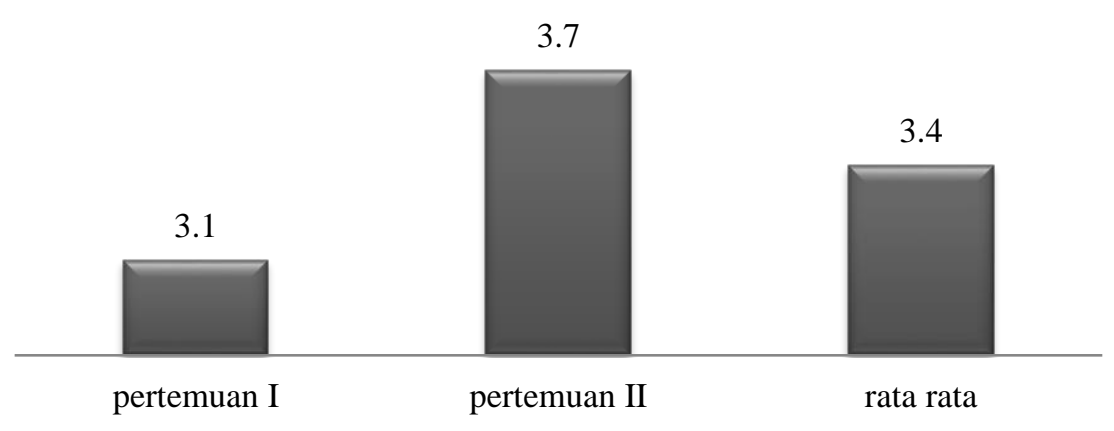

Grafik 3.4 skor rata rata aktivitas siswa data di buat (januari 2018)

\section{Data Aktivitas Guru siklus II}

Berdasarkan tabel 4.6 dan gambar 4.6 diatas menunjukkan bahwa, aktivitas guru telah memenuhi kriteria ketuntasan minimal yaitu 3,0. Dimana aktivitas guru telah mencapai rata-rata 3,4 yang berkategorikan baik 
Tabel 3.5 skor aktivitas guru pada siklus II

\begin{tabular}{|c|c|c|c|c|}
\hline \multirow{2}{*}{ No } & \multirow{2}{*}{ Aspek yang di nilai } & \multicolumn{3}{|c|}{ Skor/ siklus I } \\
\hline & & Pert I & $\begin{array}{c}\text { Pert } \\
\text { II }\end{array}$ & $\begin{array}{c}\text { Rata- } \\
\text { rata }\end{array}$ \\
\hline \multirow{4}{*}{ I } & $\begin{array}{l}\text { A. Kegiatan Awal } \\
\text { 1. Membuka pelajaran dan memeriksa kesiapan } \\
\text { siswa. }\end{array}$ & 3 & 4 & 3.5 \\
\hline & $\begin{array}{l}\text { 2. Guru menyampaikan indikator dan tujuan } \\
\text { pembelajaran }\end{array}$ & 3 & 4 & 3.5 \\
\hline & $\begin{array}{l}\text { 3. Guru memberikan stimulasi kepada siswa terkait } \\
\text { pembelajaran }\end{array}$ & 3 & 4 & 3.5 \\
\hline & 4. Guru memberikan motivasi kepada siswa & 3 & 3 & 3 \\
\hline \multirow{6}{*}{ II } & $\begin{array}{l}\text { B. Kegiatan Inti } \\
\text { 5. Guru membagi siswa yang terdiri } 4 \text { kelompok } \\
\text { siswa yang heterogen }\end{array}$ & 3 & 3 & 3 \\
\hline & $\begin{array}{l}\text { 6. Guru memberikan lembar kerja siswa (LKS) } \\
\text { kepada masing-masing kelompok dan } \\
\text { menentukan topik-topik yang harus di pelajari } \\
\text { serta memberi rangsangan pada sebuah topik } \\
\text { permasalahan dalam (LKS) yang dibagikan }\end{array}$ & 4 & 4 & 4 \\
\hline & $\begin{array}{l}\text { 7. Guru memberikan gambaran suatu masalah } \\
\text { kepada siswa dan mengorganisasikan siswa } \\
\text { untuk belajar dan berdiskusi untuk memecahkan } \\
\text { masalah yang terdapat pada LKS }\end{array}$ & 3 & 4 & 3.5 \\
\hline & $\begin{array}{l}\text { 8. Mengarahkan kepada tiap-tiap individu dalam } \\
\text { kelompok untuk melakukan identifikasi masalah } \\
\text { dan mengumpulkan data. }\end{array}$ & 3 & 4 & 3.5 \\
\hline & $\begin{array}{l}\text { 9. Guru Meminta tiap-tiap perwakilan kelompok } \\
\text { untuk mempresentasikan hasil pengolahan data } \\
\text { yang telah didiskusikan di depan kelas }\end{array}$ & 4 & 4 & 4 \\
\hline & $\begin{array}{l}\text { 10. Guru membimbing jalannya diskusi dan tanya } \\
\text { jawab dengan siswa }\end{array}$ & 4 & 4 & 4 \\
\hline \multirow[t]{5}{*}{ III } & $\begin{array}{l}\text { C. Kegiatan Akhir } \\
\text { 11. Guru memberikan kesimpulan secara singkat } \\
\text { tentang materi yang telah dipresentasikan } \\
\text { perwakilan siswa }\end{array}$ & 3 & 3 & 3 \\
\hline & $\begin{array}{l}\text { 12. Guru mengevaluasi dan merefleksi secara singkat } \\
\text { sajian materi yang disajikan oleh perwakilan } \\
\text { siswa }\end{array}$ & 3 & 3 & 3 \\
\hline & $\begin{array}{l}\text { 13. Memberi tugas kepada siswa terkait materi yang } \\
\text { sudah di pelajari. }\end{array}$ & 3 & 3 & 3 \\
\hline & 14. Menutup proses kegiatan pembelajaran & 3 & 4 & 3.5 \\
\hline & Rata-rata aktivitas guru & 3.2 & 3.6 & 3.4 \\
\hline
\end{tabular}


Untuk lebih jelasnya skor rata-rata aktivitas guru pada setiap pertemuan siklus II dapat dilihat pada gambar 3.5 berikut:

rata-rata aktivitas guru siklus II

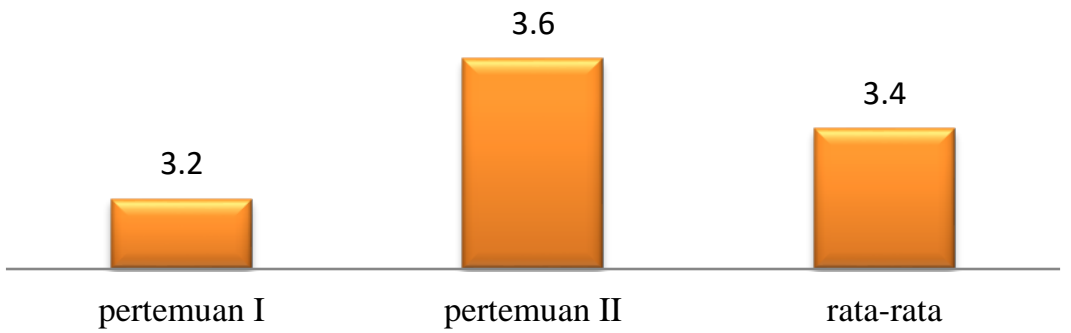

Grafik 3.5 skor rata rata aktivitas guru siklus II data di buat (januari2018)

\section{Data Hasil Belajar Siswa Siklus II}

Dari table 3.6menunjukkan bahwa ketuntasan belajar siswa pada siklus II yang memperoleh skor antara 0-69 berjumlah 2 orang siswa dengan presentase $15 \%$. Sedangkan siswa yang memperoleh skor antara 70-100 berjumlah 14 orang, dengan presentase ketuntasan mencapai $85 \%$. Hasil ini sudah lebih baik jika dibandingkan dengan skor perolehan siswa pada siklus I. Dalam hal ini indikator ketuntasan belajar siswa telah tercapai atau berhasil, dimana secara klasikal, jika jumlah ketuntasan mencapai $75 \%$, maka hasil penelitian telah tercapai dan dapat dikatakan berhasil.

Tabel 3.6 analisis ketuntasan hasil belajar siswa pada siklus II

\begin{tabular}{lccc}
\hline \multicolumn{1}{c}{ Skor } & Jumlah siswa & Presentase & Ketuntasan Belajar \\
\hline $0-69$ & 2 orang & $15 \%$ & Tidak Tuntas \\
\hline $70-100$ & 14 orang & $85 \%$ & Sudah Tuntas \\
\hline Jumlah & 16 orang & $\mathbf{1 0 0 \%}$ & \\
\hline Keterangan : & & \\
\hline Tuntas: 14 orang & & \\
\hline Tidak tuntas & $\mathbf{: 2 ~ o r a n g}$ & \\
\hline Nilai rata-rata & $\mathbf{: 8 1}$ & \\
\hline Nilai maksimum & $\mathbf{: 9 5}$ & \\
\hline Nilai minimum & $\mathbf{: 6 0}$ \\
\hline Presentase ketuntasan & $\mathbf{: 8 5 \%}$ \\
\hline
\end{tabular}




\section{Refleksi Tindakan Siklus II}

Berdasarkan hasil refleksi siklus II peneliti memperoleh peningkatan pada aktivitas belajar siswa dimana aktivitas yang berkategori cukup meningkat menjadi baik yaitu aktivitas nomor 3, 4, 5, 6 meningkat pada siklus II.

Dari hasil dan refleksi yang di lakukan oleh guru dalam hal ini peneliti dan pengamat memperoleh peningkatan pada siklus II di mana aktivita pada siklus I yang berkategori cukup yaitu aktivitas nomor 2, 3, 4, 5, $7,8,11,12$, dan 13 meningkat pada siklus II dengan skor rata-rata 3,0 yang berkategori baik.

Berdasarkan hasil refleksi pada siklus II dapat di simpulkan bahwa model discovery learning dapat meningkatkan hasil belajar dan antusiassiswa dalam proses pembelajaran. Maka langka-langka yang harus di lakukan oleh guru adalah mempermantap lagi dalam menerapkan model discovery learning.

\section{PEMBAHASAN}

\section{Aktivitas belajar siswa selama KBM berlangsung}

Pada siklus I berdasarkan hasil analisis deskriptif terhadap aktivitas siswa menunjukan skor rata-rata aktivitas siswa pada siklus I sebesar 2,7 yang berkategori cukup, pada siklus II dari hasil analisis deskriptif terhadap skor rata-rata aktivitas siswa pada siklus II menunjukkan adanya peningkatan yang sangat signifikan, dimana skor rata-rata aktivitas siswa pada siklus II sebesar 3,1 dengan kategori baik.

\begin{abstract}
Aktivitas mengajar Guru
pada setiap siklus baik siklus I maupun siklus II yang menunjukan peningkatan kearah yang lebih baik. Pada siklus I skor rata-rata aktivitas guru sebesar 2,6 yang berkategori cukup,pada siklus II skor rata-rata aktivitas guru meningkat menjadi 3,4 yang berkategori baik.
\end{abstract}

\section{Hasil Belajar Siswa}

Berdasarkan hasil tes hasil belajar siswa pada siklus I diperoleh nilai minimum sebesar 20; nilai maksimum 90 rata-rata hasil belajar siswa sebesar 61. secara klasikal dari 16 siswa yang mencapai persentase ketuntasan hasil belajar yaitu 11 siswa atau $60 \%$ yang mencapai nilai $\geq 70$ sesuai dengan nilai KKM geografi yang ditentukan oleh sekolah dan terdapat 4 orang siswa dengan presentase sebesar $40 \%$ siswa yang nilainya belum mencapai KKM yang ditentukan oleh sekolah yaitu 70. Presentase ketuntasan pada siklus I ini belum mencapai target peneliti yaitu mencapai ketuntasan belajar secara klasikal minimal $75 \%$.

Pada siklus II berdasarkan hasil tes belajar siswa pada siklus II, terlihat bahwa hasil belajar siswa memperoleh nilai minimum 60 nilai maksimum 95 , nilai rata-rata hasil belajar siswa sebesar 81. Terdapat sebanyak 14 siswa yang memperoleh nilai $\geq 70$ atau ketuntasan hasil belajar secara klasikal sebesar $85 \%$ sedangkan jumlah siswa yang hasil belajarnya di bawah KKM atau yang memperoleh nilai $<70$ sebanyak 2 orang atau $15 \%$ yang belum tuntas. Dari hasil tersebut, menunjukkan peningkatan hasil belajar yang signifikan dari siklus I ke siklus II, walaupun masih ada beberapa siswa yang belum mencapai ketuntasan belajar.Pada siklus II target ketuntasan hasil belajar siswa telah tercapai yaitu $85 \%$ siswa telah tuntas dalam hasil 
belajarnya. Hal ini penelitian dianggap telah berhasil mencapai targetnya

Dengan demikian, jawaban atas permasalahan penilitian telah terungkap yaitu pembelajaran dengan menerapkan model discovery learning berhasil meningkatkan aktivitas belajar siswa dan juga dapat meningkatkan hasil belajar geografi siswa kelas X IIS SMA Negeri 1 Wabula pada materi pokok erosi dan kerusakan tanah.

\section{KESIMPULAN}

Berdasarkan hasil dalam penelitian ini dapat ditarik beberapa kesimpulan sebagai berikut:

1. Aktivitas belajar siswa dengan menerapkan model discovery learning pada setiap siklus cenderung meningkat. Hal ini ditunjukkan dengan skor rata-rata pada setiap siklus, dimana pada siklus I skor rata-rata aktivitas siswa adalah 2,7 yang termasuk kategori cukup mengarah ke baik, meningkat pada siklus II menjadi 3,4 yang termasuk pada kategori baik mengarah ke sangat baik.

2. Aktivitas mengajar guru dengan menerapkan model discovery Learning pada setiap siklus cenderung meningkat. Hal ini ditunjukkan dengan skor rata-rata pada setiap siklus, dimana pada siklus I skor rata-rata aktivits guru adalah 2,6 yang termasuk kategori cukup dan meningkat pada siklus II menjadi 3,4 yang berkategori baik.

3. Hasil belajar geografi siswa kelas $\mathrm{X}$-IIS SMAN 1 Wabula dapat ditingkatkan dengan menerapkan model discovery Learning pada materi erosi dan kerusakan tanah. Dimana pada siklus I yaitu diperoleh nilai terendah 20 , nilai tertinggi 90 nilai rata-rata 6.1 dan ketuntasan belajar sebesar $60 \%$ yang mencapai KKM atau dari 16 siswa hanya 11 siswa yang memperoleh nilai $\geq 70$. Pada siklus II diperoleh nilai terendah 60 , nilai tertinggi 95, nilai ratarata adalah 8,1 dan ketuntasan belajar. Pada siklus II mengalami peningkatan yaitu dari 16 orang siswa ada 14 orang siswa yang yang memperoleh nilai $\geq$ 70,dengan persentase ketuntasan hasil belajar adalah $85 \%$.

\section{DAFTAR PUSTAKA}

Arikunto, Suharsimi. 2009. DasarDasar Evaluasi Pendidikan. Jakarta: Bumi Aksara.

Arsyad, S. 2000. Pengawetan Tanah dan Air. Departemen Ilmu-Ilmu Tanah. Fakultas Pertanian. Institut Pertanian Bogor.

Budiningsih, Asri. 2005. Belajar dan Pembelajaran. Jakarta: Rineka Cipta.

Hudoyo, H (1990). Strategi Belajar Mengajar. Jakarta: Proyek Pengembangan LPTK. Depdikbud.

Banuwa, I.S. 2009. Selektivitas Erosi. Penerbit Universitas Lampung. Bandar Lampung.

Banuwa, I.S. 2012. Konservasi Tanah dan Pengelolaan DAS. Penuntun Praktikum. Jurusan Agroteknologi Fak. Pertanian Unila. Bandar Lampung.

Mudyahardjo, Redja, Pengantar Pendidikan; Sebuah Studi Awal tentang Dasar-Dasar Pendidikan 
pada Umumnya dan Pendidikan di Indonesia, Jakarta: Raja Grafindo Persada, 2000.

Galuh Arika Istiana, Agung Nugroho Catur, dan J.S Sukardjo "penerapan model pemebelajaran discovery learning untuk meningkatkan aktivitas dan hasil belajar siswa kelas XI IPA semester II SMA Negeri 1 Ngemplak tahun pelajaran 2013/2014" Jurnal Pendidikan Kimia (JPK), Vol. 4 No. 2 Tahun 2015. Universitas Sebelas Maret

Resiningtias, Mega. 2016"Penerapan Model Discovery Learning Untuk Meningkatkan Hasil Belajar dan Keterampilan Proses Sains Siswa Kelas VIIa SMPN 2 Kota Bengkulu”. Skripsi FKIP Universitas Bengkulu: Tidak diterbitkan

Erlianti. 2016 ."Penerapan Model Diskoveri Terbimbing Dengan Pendekatan Saintifik Untuk Meningkatkan Hasil Belajar dan Kemampuan Proses Sains Di Kelas VIIIG SMPN 7 Kota Bengkulu" Skripsi. FKIP Universitas Bengkulu: Tidak Diterbitkan.

Susanti, dkk. 2016. "Pengaruh Model Discovery Terhadap Keterampilan Sains dan Hasil Belajar Siswa Kelas VII Tentang IPA SMP Advend Palu”. Jurnal Sains dan Teknologi Volume 5 No 3. 2017 